Intermedia International e-Journal, Spring -June- 2016 3(1)

DOI NO: 10.21645/intermedia.2016319250 Submit Date: 13.05.2016 Acceptance Date: 20.05.2016 ISSN: 2149-3669

\title{
TECHNOPHILE INDIVIDUAL IN SOCIETY: EXAMPLES FROM CINEMA TO TECHNIUM*
}

\section{Toplumdaki Teknofil Birey: Sinemadan Technium'a Örnekler ${ }^{* *}$}

\author{
Research Assistant, Özgür ÇALIŞKAN ${ }^{* * *}$ \\ Anadolu University, Faculty of Communication Sciences, \\ Department of Cinema and Television, \\ Eskisehir
}

\begin{abstract}
Since technology invaded human life, there has been a strong relationship between humans and machines. In this relationship, similar to other relationships in which humans are involved, there are emotions. When technology brings irresistible innovations and creates a multi-mediated environment, it becomes more difficult to reject the materiality of technology. In time, the acceptance of machines into life has created a new society which cannot exist without machines, and the individual's life in this new society has become dependent on machines. For some individuals, this interdependence may become an enthusiasm and even addiction, intentionally or unintentionally. Technophilia and technophile are useful burgeoning terms to describe the devotion of humans to new technologies and other technological inventions. This content-based descriptive paper aims to study technophilia in the context of technological reductionism. The research includes examples from science-fiction cinema and Hatsune Miku (virtual pop singer) with the concept of technium. The paper explores the term technophilia from the cultural perspective for relationship between human and machines, presenting this new notion as the element of human identity.
\end{abstract}

Key Words: technophile, science-fiction, cinema, hologram, descriptive

Özet: Teknolojinin insan hayatına girdiği günden bugüne, insan ile makineler arasın güçlü bir ilişki oluşmuştur. İnsanın girdiği her ilişki gibi bu ilişkide de duygular yer almıştır. Teknolojinin insan hayatına getirdiği kolaylıklar ve çok araçlı çevre düşünüldüğünde teknolojinin varlığını inkâr etmek zorlaşmaktadır. Makinelerin, insanlar tarafından Kabul edilerek gelişen yaygın kullanımları, insanı makineye giderek daha da bağlı kılmaktadır. Bazı bireyler için bu karşııklı bağlılık isteyerek ya da istemeyerek zamanla arzu ve hatta bağımlılığa dönüşmüştür. Teknofili ve teknofil insanın makineye olan hayranlığına ilişkin kullanımı yaygınlaşmakta olan terimlerdir. Bu içerik odaklı betimsel çalışma teknolfili kavramını teknolojik indrigemecilik bağlamında açıklamayı amaçlamaktadır. Çalışma technium kavramı ile bilim kurgu filmlerinden ve Hatsune Miku (sanal pop şarkıcısı)

\footnotetext{
* This paper is revised and extended version of the verbal notice titled "Technophile Individual in Society: the Enthusiasm of Techno-humans for Machines and New Media" which is presented at the 7th International Conference on Interdisciplinary Social Sciences, Barcelona, SPAIN.

${ }^{* *}$ Bu çalışma, 7. Uluslararası Disiplinlerarası Sosyal Bilimler Konferansı'nda sözlü olarak sunulan “Toplumda Teknofil Birey: Tekno-insanların Makine ve Yeni Medya İçin Duyduğu Heyecan” başıkılı bildirinin yenilenmiş ve geliştirilmiş halidir.

**** ozgurcaliskan@gmail.com; ozgurcaliskan@anadolu.edu.tr.
} 
örneklerini içermektedir. Çalışma teknofil kavramını insan kimliğinin yeni bir öğesi olarak sunarak teknofili kavramının insan ile makine arasındaki ilişkide kültürel bağlamdaki yerini ortaya koymayı amaçlamaktadır.

Anahtar Kelimeler: teknofil, bilim kurgu, sinema, hologram, betimsel

\section{Introduction}

First Bruce Mazlish (1967, p.14) claimed "we cannot think any longer man without a machine" in 1967, then Sherry Turkle discussed the issue of people growing up with computers and loving them and identify themselves as machines in 1984. Today, there is a new direction and discussion about the relationship between human and machines. As Mazlish and Turkle emphasized the future of interaction between machines and human, today, this discussion has various aspects and one of them is that how people feel about the technology and its machines. Only same thing about the discussion is that trying to predict the future. It is discussed that the digital future is monolithic; "everything will be digital, everyone will be wired, all media will converge into one" removing physical world away (Agre, 2009, p.325). In addition, "technology proposes itself as the architect of our intimacies and it is seductive when what it offers meets our human vulnerabilities" and "sociable robots meet our gaze, speak to us, and learn to recognize us" (Turkle, 2011, p.1-2). As postmodern philosophy tries to discuss the simple binary opposition such as male/female, good/evil, homosexual/heterosexual and human/nonhuman, it has basically changed the discussion. Moreover, it brought new aspects about the binary opposition. About the technology and science-fiction, new binary oppositions have been created such as utopic/dystopic which is related to the positive and negative aspects about the future of technology and machines. Obviously, the future of the relationship between human and technology will be shaped through what and how the human feel about the machines and this is strongly related to the feelings of love and hate. As the feeling of hate is discussed from different aspect in the history of human from wars in the real world to the various dystopian science-fiction films, the feeling of love should be discussed not to predict the future from one aspect. This paper aims to study the concept of technophilia as a socio-cultural term for loving the technology and machines enthusiastically with comparison of science-fiction cinema with today's world in the context of technological reduction. As the paper's structure is content-based, qualitative descriptive analysis is used to discuss the technophilia and technophile terms. For the analysis, how and why questions are asked to purposefully chosen examples. The answers that are related to the terms are brought into discussion.

\section{Why We Love Technology?}

Culture is a concept which has very large meaning and defined as an integrated pattern of human knowledge, belief, and behavior that depends upon the capacity for symbolic thought and social learning (Kroeber and Kluckhohn, 1952). This meaning guides us to the idea of culture as something closely related to our everyday life. Things that we do, watch, listen and read, directly affect our culture and all of these things also help to improve our own culture. Therefore, if we think that our everyday life is related with our culture, we can say that our definition and perception of technology is influenced by our everyday lives. It means that when we continue our daily lives, there are perceptions which affect us when we use technology.

As the world is globalized; different people from different countries, different cultures, different generations, having different personal experiences and knowledge, all share same technological products such as; mobile phones, cars, mp3 players, computers and computer products and etc. These technological products create their own era and culture world widely. There are global rules, knowledge, customs, and common behaviors when people use those machines. Therefore, this situation makes the technology to a cultural subject. Culture is not something that includes only one element of an individual, it includes various kinds of elements. As culture involves identity, it involves technology too. It means that, a technology product can be a 
part of a person's identity. For this reason, people need to like their belongings, and to love, they need to like those devices' appearance to identify with them. David Orr (2002, p.25-26) mentions that as a human we need "emotional attachment" and "deep affection" to get inspired by the object. For this reason, human needs "emotional attachment" and "deep affection" for technology too.

\section{From Technophobie to Technophilia}

The word technophile and its other versions technophilia and technophilic are the notions which penetrate into our language and lives during the period of transition between modern and postmodern terms. The first known use of the term technophile is in 1968 (Merriam-Webster's Learner's Dictionary, n.d) , just 3 years later than its opposite technophobia (Merriam-Webster's Learner's Dictionary, n.d.). Therefore, it is claimed that; in a literal way, people needed to define their fears before their love for the thing which intrudes their lives; technology. This situation is important because the need of finding definitions for interaction between human and technology proves that this interaction always carry emotions, mainly love and hate.

In the beginning of the 21st Century, these emotions are quite different than before. The existence of these emotions shape all the way of the relationship between both sides and affect the identity of human in the way of being techno-human for SF cinema and the world of today. Meanwhile, the emotions that human feel for technology has been altered during the 20th Century, concurrent with SF cinema and today. In SF cinema, technology has been figured as a dark phenomenon from Metropolis (Fritz Lang, 1927) to the Matrix Revolutions (Andy \& Lana Wachowski, 2003) and technology represented as the enemy of human destroying and enslaving the human (Dinello, 2005, p.1-2). Therefore, it is important to explain this representation and its reasons in general. Then it is also important to explain the technophilic emotions of techno-human after the technophobic emotions.

It is interesting that human has both emotions for technology today; sometimes we are afraid of machines around us, and when we are getting closer to them, we even become addicted to them. For this situation, SF cinema plays a significant role in showing people the possible futuristic human and machine relation. In this regard, considering SF cinema, techno-human is in between something like Terminator and Terminator 2 (both James Cameron, 1984 \& 1991). In the first Terminator, the machine T-100 is sent to the world from future by a machine to destroy humanity, but in the second movie, the same T-100 comes to protecting human. Thus, it is a very similar feeling that we have today. Sometimes we use machines we do not want or like, and sometimes we love our machines, although we know that they are dangerous or harmful for us. Therefore, as we feel all opposite feelings about everything, we feel the same opposite emotions for the machines too, and today, human has -phobic and -philic feelings for technology. However, for the reason that technophilia comes after technophobia, historically and literally, it is more important to concentrate on technophilia idea which is a growing emotion on human feelings, taking the place of technophobia. For sure, technophobia is still there and will always be there, but significantly, technophilia has risen in the last decade and there has been balanced between our hate and love emotions for technology.

The general definition for technophile is "likely to be a person who sees the positive benefits deriving from technology and advocating increased use of technology as a solution to economic, social and political problems within the society" (Sociology Index, n.d., para. 1). According to Dale Carrico (2006) "a technophile is a person to whom we attribute a naïve or uncritical enthusiasm for technology." As -philic term is used for technophilia, it is also a part of discussion about if technphilia is an addiction or disease. It is not clear yet the term such as "Internet addcition" is useful because overrated Internet usage is still called as a habit. However, it is important to mention that a habit is a routine which is the level before addiction. For this reason, technophilia should not be considered as the addiction for technology for any reason. Actually and easily it means just loving the technology for any reason; for instance a machine can make us happy, make our lives 
easier, and make represent us in a good position in public. Therefore, we have technology because we think it makes us better, and it is the idea of what technophilia means in reality. Furthermore, technophilia does not have to be on purpose, and it is not always a conscious feeling. For example, many people have refrigerators in their houses, and for sure they never think they love their refrigerators. However, deep inside, we already depend on this device, and if when we do not have the machine in the kitchen, we feel that we need it again, it is technophilic feeling. The feeling is like when it is said "I miss my computer" when we are on holiday, or if there is no network connection around when we need it, we feel an obligation and pressure to find a place to connect to the Internet, or just decorating our cars, mobile phone and computers to make them look like as if we want, as we love.

Similar to technophile, technophilia is generally used in the sociology area to define devotion of human to new technologies and other technological inventions which include any kinds of computers, mobile phones, cars, domestic electronic products, visual technologies such as television or console/PC games and etc. Besides, the concept of technophilia includes not only one way direction between techno-human and technology; it may also be used for one's communication within society through the love of technology; how a person behaves in the society using his/her feeling of love for technology. In addition, technophilia may be explained as a situation when one is unable to live without technology; maybe we do not name ourselves as technophile, but if we feel sick, desperate, disabled, powerless or forsaken when we could not reach the technology and machines that we had before; it means that we are addicted or dependent on those machines and this addiction brings obligatory affection out of our control or enthusiastic affection with our desires when we want to be with technology on purpose.

About technophilia, Kevin Kelly (2009) emphasizes; "our transformation from smart hominid into Sapiens was midwifed by our tools, and at our human core we harbor an innate affinity for made things. We are embarrassed to admit it, but we love technology ... our identity with technology runs deep, to our core". In addition, Kelly mentions the story of a teenage girl whose parents take away her mobile phone and then she becomes physically ill; having dizziness and nausea and she never gets out of bed. It reminds the human of today, especially teenagers, not all but many of them cannot live without the machines which are extensions of their body and identity; mobile phones, computers, mp3 players and such. Besides, fashion of technology is an additional agent for people, especially for young people. For example; according to a research; mobile phone as a technology is the symbol of popularity, beauty and excitement (Katz et al. 2003, p.79). Thus, when people buy a machine; car, computer, television and even refrigerator; style, colour and shape of the machine is important for them because they want to buy a machine they like or they love the appearance of it. Therefore, liking is the first step of human and machine relationship. Moreover, our tastes change in time, we are bored with our machines and we do not like them so we change them because we lose the intention to connect with our machines. Therefore, figuratively, people design their environment with the products and machines they love in a sense and it creates technophilic space for the techno-human who is surrounded by loved-technology.

There are many fan pages on the Internet about cameras, cars, motorcycles, mobile phones, guns, video games, computers and domestic products, proving that, somehow, technology is loved. Technophile individual creates evocativeness of a technological device, with all mental and emotional process giving emotional meaning to it. For her idea about evocative object, Sherry Turkle mentions "we think with the objects we love, and we love the objects we think with" (Turkle, 2007, p.5). Therefore, today, everybody has some objects to think with and technology does not leave alone anyone to think without it, it always pressures to human to think with it, telling them to find an object to like. As Turkle mentions the objects, the idea of technophilia is conducted by objects, but the line of technophilia starts when we have the machines that we do not need around us. In addition, human creates connection with the objects with their participation in our lives and the objects become companions for us. 
For instance, in 2008, the term nomophobia (no mobile phobia) is firstly used in the United Kingdom (D'Agata, 2008). The term defines people who afraid of living without a mobile phone and its contents such as mobile Facebook. In addition, a study by SecurEnvoy revealed 66 percent of participants do not feel comfortable when they think their mobile phones are lost. Importantly, this rate is increasing to 76 percent between the age group of 18-24 (SecurEnvoy, 2012). As a result of a similar study by Baylor University, 60 percent of college students admitted the addiction to their devices (Goodrich, 2014). These studies reveal that, people deeply have a relationship with their machines. As an example, Annalee Newitz (2007, p.88-89) mentions her computer is irreplaceable saying "I would recognize the feel of its keyboard under my fingers in a darkened room". She even keeps the blankets from covering its vents so it doesn't overheat and she claims that they belong to each other. Furthermore, when she meets someone on WizNet, she imagines his body as a green light on the screen and his breath as the sound of fan cooling the CPU of her laptop. Another example of love for evocative object as a machine might be Pramoda Meduri's poem for her laptop. On her blog (Pramoda, 2011), she publishes her poem called "Disaster Survived - I Love My Laptop" dedicated to her laptop. As a note for the poem she mentions "I love my laptop; it's been with the most of the time than that of my loved ones! I find no reason not to take it to my heart, except that another laptop can just replace it! But this is my first one, just like the fragrance and freshness of first love!"

\section{Technium and Technophile Individual}

When Kevin Kelly (2009) describes today's society as the technium, -the whole adaptive system of technology and culture-, he tells the relation between the technium and technophilia saying;

"We keep specific technology around not only because it may be useful, but because we like to have it around. The gear, devices, networks form an interdependent ecosystem of interrelated parts, and we have a technophilia for its survival. ... We continue the manufacture new ideas and new artifacts, not because we always need them, but because the technium needs, and because we find technium attractive."

Therefore, today's human may be the part of Kelly's technium also as technophile existence; lost in one's desires and love for the inorganic entities. Technium "extends beyond shiny hardware to include culture, art, social institutions and intellectual creations of all types" including "intangibles like software, law and philosophical concepts" (Kelly, 2010, p.12). Kelly (2010, p.182-183) describes technium comparing three evolutionary vectors of life in triads of biological evolution (Figure 1) and technological evolution (Figure 2). As it seems, functional/adaptive vector of biological evolution changes to intentional/open vector. In other words, "functional vector is occupied by an equivalent force which is the intentional" and further "in technium the adaptive function is not unconscious, as it is natural selection, instead it is open to human free will and choice" (Kelly, 2010, p.183).

When the concept of technophilia is considered, an individual who is a member of technium, has two directions to become technophile person. When technological evolution changes functional vector to intentional; for an individual, even it is open to human free will; the choices for being technophile have two directions: intentional or unintentional. Therefore, it is possible to have quadrangle around the individual from technium to technophilia (Figure 3). Figure 3 explains the two directions for being technophile individual of technium and as technium allows the individual to have free will for an intentional vector, being technophile still occurs in two directions. 
Figure 1: The Triad of Biological Evolution

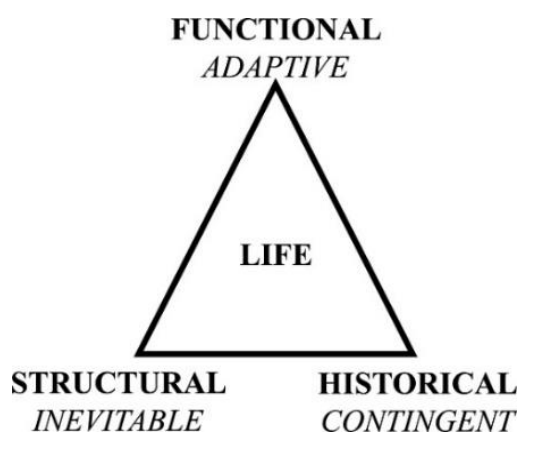

(Kelly, 2010:182)
Figure 2: The Triad of Technological Evolution

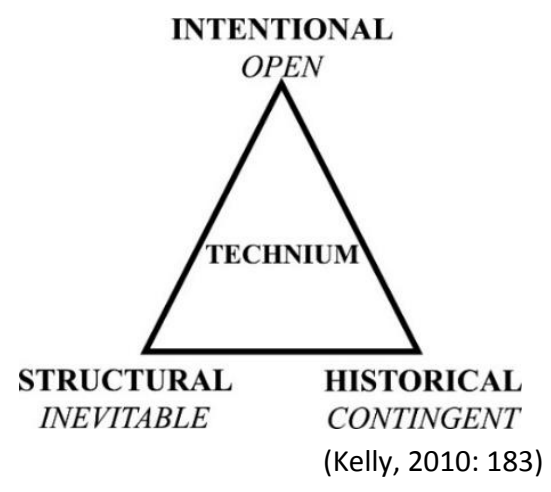

Figure 3: The Quad of Technophile Individual in Society

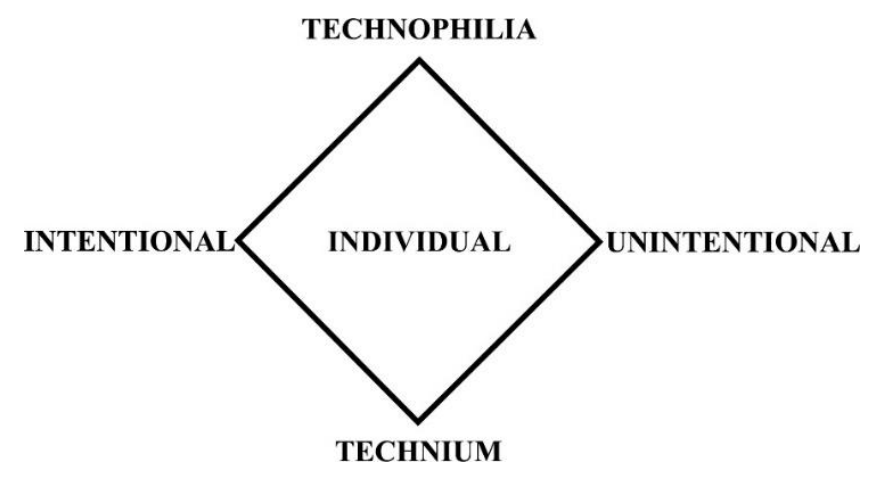

\section{Love for Machines: Dead or Alive}

Two movies of David Cronenberg; Videodrome (1983) and Crash (1986) are about the sexual desires of human for technology; significantly for machines including cars and television. In Crash, Cronenberg brings the machine (car) and human face-to-face situation and introduce an evolutionary process of human; showing how one feels when one is in a car or has/sees car "crash" and how one can be altered after the metal -substance of the car- penetrates one's body. Cars can be considered as a 1,500 kg wearing machine which carries us with $100 \mathrm{~km}$ per hour adapting the human to its own speed and new environments; ways and roads (Frascara, 2003, p.95). Therefore, car is one of the first milestone inventions which people use often in their daily lives; thus it is impossible to ignore the consequences of human and car interaction. World Health Organization describes the car as a part of our body, drug and social communication (Naatanen and Summala, 1976, p.13 cited in Frascara, 2003, p.195) and if we assume the car as a "drug"; it explains what the initial point is of J. G. Ballard for creating a human figure with desired cars and why Cronenberg had desire to reflect this fetish on screen adding his own imagine and visuality.

The protagonist of Crash; James has a car crash and after this experience he has a leg prosthesis with metal rods and wears them until he gets healthy. During this process, he gets closer to cars emotionally because, he feels the same substance -metal- of his car inside his body and he remembers the sound of crashing metal; thinking his experience inside the car that gives him an opportunity to have an empathetic connection with his car so he feels like a part of the car. It makes him a new person, the improved one as a superior machine with his metal part so it is unavoidable to love this new part of the body; and there is only 
one thing to share this feeling with him; his car. When James follows his desire for the machine, his adventure brings him to another character also a "hero" of the movie Vaughan, who takes James' attention to absolute sex that extended with the violence (Bukatman, 1993, p.292). For this reason, having excited experience of death from the first person point of view is mainly possible with the car; the death of human and machine at the same time, sensing all the moments of dying process so it is one of the sources for loving the car. Scott Bukatman claims crashing is the division, physically and spectacular, to reach the completed integration of a technologically eroticized and violent death (1993, p.293). Therefore, it emphasizes; besides his body, James', Vaughan and others' desires are technosized, becoming the new identity of techno-human; even this new identity and love brings one to the death.

Similar to Crash, today, mainly on YouTube and other video sharing websites, car and any other vehicles crash videos are watched by millions of people (nigel page, 2005; Fjakone, 2006; Discovery, 2008). People record the videos of a crash if they are witnesses and then they upload the videos to share through the Internet, the ultimate experience that they see or they have. Additionally, governments, traffic and police departments contribute their security camera records of crashes to the television news and the Internet. Moreover, it is possible to find crash and accident thematic web pages which have photo or video collection of vehicles which are wrecked by a crash (http://www.wreckedexotics.com/; http://www.car-accidents.com; http://www.th ecarcrash.com/). When people share, they also comment, discuss and make some jokes and fun out of the crashes and visuality of wrecked vehicles. For this reason, technophilia may be considered one of the reasons for why people are interested in watching these videos and looking at the photos because even though content of some visual items might be scary and violent, the curiosity of seeing the distortion and destruction of a machine which is part of everyday life gives the pleasure of viewing at that moment. Seeing the death of a machine and makes one feel very close to the death more than ever. As Bukatman (1993, p.192) mentions when referring to the Crash and its story; "it -meaning the relationship between human and cars- represents the ultimate interface with the realities of a technologized existence". Likewise, in the movie Artificial Intelligence (Steven Spielberg, 2001), Spielberg shows a more futuristic picture of human love for the combination of metal, robot and death. The movie happens in the future that useless robots are destroyed, exploded, split and burned in the live show to entertain people. The show in the movie is very similar to today's illegal car crash shows where people destroy their retired cars, crashing at each other or do some dangerous driving and jumping movement with many people watching and encouraging them cheering. It is the junction of common desires of both human kind in SF film and real life; having a pleasure using a machine and then destroy it.

Human identifies the car and any other vehicles as sexual objects for their design and usage as well. For instance, cars have always been the space for people to have sex. In the car parks, open-air cinemas, at nights or isolated places, having sex in the car is considered as a sexual fantasy. Other than this, in the movies, especially in adult movies, the scene of a girl washing a car is generally used as stimulating scene for men who have known car-madness gene. For only concentrating on cars as affected subject, technophilia is the reason for this likeness as car-holic or in the same meaning techno-holic which is similar to the notion of technophilic. Sometimes all these feelings may go further than identical desires to physical desires for the car. For instance, in Canada, 45-year-old Sandy Wong (2007) was condemned after his three sexual acts to the classic cars, masturbating on the hoods of the cars and he mentioned he was attracted to a vehicle's roof top in particular saying "it's curved like a woman's body, the sex appeal, it felt good" (The Smoking Gun, 2007).

Another movie of David Cronenberg; Videodrome (1983) is a substantial example for Guy Debord's society of spectacle and Scott Bukatman defines this notion as a science fiction of spectacle referring Debord's idea which emphasizes the spectacle is an addiction. According to Bukatman (1993, p.37) "the spectacle stimulates the desire to consume...a desire continually displaced onto the next product and the next." 
Therefore, television mainly takes part in the society of spectacle and in this sense; it produces its own addiction; image addiction; loving the voyeurism, loving the TV. In Videodrome; image, reality, hallucination and psychosis are reflected as merged and it constructs a detailed portrait of image addiction and viral invasion (Bukatman, 1993, p.85). While the main character of the movie Max Renn desires the Videodrome, in fact, he desires the world of television, world of image and spectacle which he is being addicted to and exposed by. In addition; there is a strong relation between addiction and love for the spectacle. Actually, as an object, the television machine is not the one that is desired; it is the content of television that makes human addicted; the things inside of it, the thing that we watch. In time, image addiction brings Max Renn to the point of seeing hallucination and he cannot be sure of what is real and what is not. He sees video cassette as woman's breast, television screen as woman's lips, video cassette player as woman mouth and from TV, Nicki Brand, a psychiatrist calls him from inside the TV "I want you Max", "Come to me, Come to Nicki" and television is not only a machine anymore, it becomes an object of sexual desire. Furthermore, it does not matter what we see on the television screen is real or not. When we see the spectacle, it is enough for techno-human to believe because techno-human is already amazed by the image.

In the last five years, Microsoft "demonstrated a virtual human, Milo who recognizes people it interacts with and whose personality is sculpted by them." Moreover, scientists have been working on robots who can "make eye contact, track our motion and gesture in a show of friendship"(Turkle, 2011, p.2-8). Similarly, Hatsune Miku as the first virtual 3D hologram singer in the world, was made of Vocaloid 2 synthesizing technology by Yamaha Company. The meaning of her Japanese name tells exactly what she is; Hatsu means the first, Ne means sound and Miku means future (Mikufan, 2008). Besides, other than the image of television, Hatsune Miku is the new image of the 21st Century. Her videos are watched by thousands of people on YouTube and other international and local video sites. She gives live concerts to thousands of people (Raito Kun, 2013). In addition, her appearance and her songs are loved by people, although she is not real. In the concerts, she stands on the stage as hologram from a projection and fans scream for her when she appears on the stage. Her physical appearance is so similar with the girls in other Japanese animations and hentai that is Japanese adult animation videos for +18 ; very short skirt, long blue air, tiny and cute face, very skinny body, long legs and her clothes are the same as those of a school girl's. In addition, Hatsune Miku is not only a singer, but also the digital popular icon, and sexyually desired figure. This situation is technophilia whether people like her as a technology, as a person or as an artist because she exists virtually/technologically. Indeed, her voice is given by a real Japanese singer Saki Fujita but, she never appears so we only see Hatsune Miku, an unreal one. Therefore, our admiration for the virtual hologram singer takes us to the identical alteration of techno-human; literally, if we love Hatsune, we love all environment and technology she belongs to. The movie S1MONE (Andrew Niccol, 2002) similarly tells the story of a movie director who has an emotional relationship with the digital actress Simone. Simone is just a computer product used in the movies, but her image and appearance is so authentic to make someone love her. Therefore, Hatsune Miku and Simone have common features as they are both just a software, but the interesting thing is that Hatsune is visually and virtually real and loved by people.

\section{In Lieu of Conclusion}

On the whole, we feel positive desires for all technology around; from mobile phones to the car, and in some situation we feel helpless without them and we realize we need them. In this regard, the meaning of love has also been changed because, today, it is not important what we love because there are many things to love. The important thing is why we love, and at this point, it is easy to explain the reason of our love for technology. It helps, connects, carries, saves and supports us. In short, it makes our lives easier. On the other hand, there are still limitations on this emotional positive relationship between technology and us, for there is still the feeling of fear that comes from the past. Further, as to all examples about technophilia, they are also the result of technophobia too. Destroying the robot, watching the death of car, see the brings the desire of seeing the end 
of something that we are afraid of, so the line between the technophobia and technophilia is very thin here because, as human being, we want to control the technology because we do not want them controlling us for the reason that, partly, we believe that they are dangerous to us as we see in Terminator that machine might come to kill us from the future or the machine might be deceiving us as what happens in the Matrix.

All devices and networks make us feel more comfortable, more independent, more social and sometimes more miserable. All people are not technophile yet, however developing technologies make people more dependent on the world of technology, to the technium. Interdependency between technology and human is increasing with the development of every new technology. As people use more machines, they are also redefining their relationships with the machines. The machines are becoming more evocative for people every other day. In the future, technophilia may take the place of technophobia. Technium helps people to overcome their fears of technology. As for nomophobia, there will be more people who are afraid of living without technology and technophilia might be considered to be the last. For all, feelings of love and hate that we have for technology are balanced in real life so today we can love and hate the machines. However, still, we have not come to the point of the predicted war between human and machines, love and hate; we do not hate them enough to destroy and we do not love them enough to kill ourselves, yet.

\section{REFERENCES}

Agre, P. E. (2009). Designing genres for new media: Social, economic, and political contexts. In L. A. Lievrouw and S. Livingstone (Eds.), New media volume II technology: Artefacts, systems, design (pp.325-348). London, England: SAGE.

Bukatman, S. (1993). Terminal identity: Virtual subject in postmodern science fiction. London: Duke University Press.

Carrico, D. (2006, August 12). Technoprogressivism: Beyond technophilia and technophobia [Web log post]. Retrieved from http://ieet.org/index.php/IEET/more/11

D’Agata, C. (2008, April 3). Nomophobia: Fear of being without your cell phone [Web log post]. Retrieved from http://web.archive.org/web/20080412042610/http:/www.wsbt.com/news/health/17263604.html

Dinello, D. (2005). Technophobia!: Science fiction visions of posthuman technology. Austin: University of Texas Press.

Discovery. (2008, November 10). Destroyed in Seconds - Stock Car Crash [Video file]. Retrieved from https://www.youtube.com/watch?v=wQ4 JIDXMUw

Fjakone. (2006, November 23). Car Crash, Traffic Accident @ Rijeka [Video file]. Retrieved from https://www.youtube.com/watch?v=d39s3FidkNo

Frascara, J. (2003). The third skin: Wearing the car, ignoring safety. In L. Fortunati, J. E. Katz and R. Riccini (Eds.), Mediating the human body (pp.195-199). New Jersey: Lawrence Erlbaum Associates.

Goodrich, T. (2014, August 28). Cellphone addiction is 'an increasingly realistic possibility', baylor study of college students reveals. Retrieved from Baylor University Media Communications website: http://www.baylor.edu/mediacommunications/news.php?action=story\&story=145864

Katz, J. E., Aakhus, M., Kim Dong, H. \& Turner, M. (2003). Cross-cultural comparisons of ICTs. In L. Fortunati, J. E. Katz and R. Riccini (Eds.), Mediating the human body (pp.75-86). New Jersey: Lawrence Erlbaum Associates.Inc.

Kelly, K. (2009, June 8). Technophilia [Web log post]. Retrieved from http://kk.org/thetechnium/technophilia/

Kelly, K. (2010). What technology wants. New York: Viking/Penguin Books.

Kroeber, A. L. \& Kluckhohn, C. (1952). Culture: A critical review of concepts and definitions. Massachusetts: Harvard University Printing Office.

Mazlish, B. (1972). The fourth discontinuity. Technology and Culture. 8 (1), 1-15.

Merriam-Webster's Learner's Dictionary. (n.d.). Technophile. Retrieved from http://www.merriamwebster.com/dictionary/technophile 
Merriam-Webtser's Learner's Dictionary. (n.d.). Technophobia. Retrieved from http://www.merriamwebster.com/dictionary/technophobia

Mikufan (2008, March, 4). About/contact [Web log post]. Retrieved from http://www.mikufan.com/about2/\#sthash.facEa3cR.DJcrVVLY.dpbs

Naatanen, R. \& Summala, H. (1976). Road-user behaviour and traffic accidents. New York: American Elsevier.

Newitz, A. (2007). My laptop. In S. Turke (Ed.), Evocative objects: Things we think with (pp.86-91). Massachusetts: MIT Press.

Nigel page (2005, December 21). Smart car crash [Video file]. Retrieved from https://www.youtube.com/watch?v=ju6t-yyoU8s

Orr, D. W. (2002). The nature of design: Ecology, culture, and human intention. Oxford: Oxford University Press.

Pramoda, M. (2011, September 1). Disaster survived \& I love my laptop!!! [Web log post]. Retrieved from http://yedilmangemore.blogspot.com.tr/2011/09/disaster-survived-i-love-my-laptop.html

Raito Kun. (2013, May 8). Hatsune Miku Live Party 2013 in Kansai [Video file]. Retrieved from https://www.youtube.com/watch?v=rL5YKZ9ecpg

SecureEnvoy. (2012, February 16). $66 \%$ of the population suffer from nomophobia the fear of being without their phone [Web log post]. Retrieved from https://www.securenvoy.com/blog/2012/02/16/66-ofthe-population-suffer-from-nomophobia-the-fear-of-being-without-their-phone/

Sociology Index. (n.d.). Technophile. Retrieved from http://sociologyindex.com/technophile.htm

The Smoking Gun. (2007, November 27). Auto eroticism, literally [Web log post]. Retrieved from http://www.thesmokinggun.com/documents/crime/auto-eroticism-literally

Turkle, S. (1984). The second self: Computers and the human spirit. New York: Simon \& Schuster.

Turke, S. (2007). Evocative objects: Thing we think with. Massachusetts: MIT Press.

Turkle, S. (2011). Alone together: Why we expect more from technology and less from each other. New York: Basic Books. 